\begin{tabular}{|c|c|c|c|}
\hline & \multicolumn{2}{|c|}{ R\&S - RESEARCH STUDIES ANATOLIA JOURNAL } & \\
\hline Research Studjies & https://dergipark.org.tr/rs & Vol:3, Issue:1 ; pp:37-47 & $=$ \\
\hline
\end{tabular}

SOCIAL AND HUMAN SCIENTIFIC

Varlı, E. B. (2020). “Garanti Markalarından Doğan Sorumluluğun Sigortalanması”, R\&S - Research Studies Anatolia Journal, Vol:3 Issue:1 ; pp:37-47

Anahtar Kelimeler: Garanti Markası, Sorumluluk,

Keywords: Guarantee Mark, Liability, Assurance,

Güvence, Sigorta, Ürün Mali Sorumluluğu Sigortası

Insurance, Products Liability Insurance

Makale Türü Araștırma Makalesi

\title{
GARANTİ MARKALARINDAN DOĞAN SORUMLULUĞUN SİGORTALANMASI
}

\author{
Insurance of Liability About Guarantee Marks \\ Elif Banu VARLI ${ }^{1}$
}

\begin{tabular}{l} 
Geliş Tarihi / Arrived Date \\
06.01.2020 \\
\hline Öz \\
Garanti markaları, marka sahibinin kontrolü altında \\
bu markayı kullanmaya yetkili kılınmış birçok \\
işletme tarafından üretilen mal ve/veya hizmetlerin \\
ortak özelliklerini, üretim usullerini, coğrafi \\
menşelerini ve kalitesini garanti etmeye yarayan \\
işaretlerdir. Garanti markası sahibinin sorumluluğu \\
alıcıya, mal ve hizmetlerin belirli standartlarda \\
olduğuna ilişkin bilgi vermek ve alıcıda oluşan \\
güvene dayalı sözleşme öncesi görüşmeler \\
aşaması̈nda ortaya çıkan bir sorumluluk olduğu \\
düşünülmektedir. Garanti markasına güvenerek \\
işlem yapan üçüncü kişiye karşı sorumluluğunun \\
hukuki dayanağını güven sorumluluğu \\
oluşturmaktadır. Garanti markasının sağladığı güven \\
ile üçüncü kişi arasında edim yükümünden bağımsız \\
kanuni bir borç ilişkisi ihlal edilmekte ve üçüncü kişi \\
bu nedenle oluşan güven zararlarının tazmin \\
edilmesini istemektedir. Garanti markasının temin \\
ettiği bu güvenden doğan sorumluluğun Sigorta \\
Hukuku açısından sigortalanması hususuna yer \\
verilmiştir.
\end{tabular}

\section{GíRiș}

Bir tüketici yeni bir akıllı telefon satın aldığında, farklı modellerin Wi-Fi, Bluetooth ve 4G (yakında 5G) gibi bir dizi ortak standart uygulayıp uygulamadığını kontrol etmektedir. Benzer şekilde, tipik bir tüketici, bir microUSB konektörü kullanılarak şarj edilen bir telefondan Apple'ın "Lightning" konektörünü veya daha yeni USB-C konektörünü kullanan bir telefona geçtiğinde, şarj kablolarını da değiştirmesi gerektiğini bilir. Çoğu tüketici, bu teknolojilerin arkasındaki standartların nasıl çalıştığı konusunda belirli bir fikre sahip değildir. Bununla birlikte, tüketiciler bu basit ticari

D Arş. Gör., Ankara Sosyal Bilimler Üniversitesi Sosyal Bilimler Enstitüsü, Özel Hukuk Anabilim Dall, banu.varli@asbu.edu.tr, Ankara/TÜRKIYE 
isimlerle ilişkilendirilen işlevselliğe aşinadırlar. Böylece teknik standartların adları tüketiciler için kritik bir bilgi rolü üstlenir.

Standartlar ve bunlara verilen adlar, genellikle sonunda bir endüstri standardı haline gelen özel teknoloji geliştiren firmalar (örneğin, Adobe Taşınabilir Doküman Formatı (PDF)) veya daha sıklıkla standart geliştirme olarak bilinen gönüllü endüstri birlikleri tarafından oluşturulmaktadırlar. Marka, ayırt edicilik işleviyle birlikte üzerinde kullanıldığı mal veya hizmetin kalite simgesine dönüşmektedir. Bu nedenle marka bir anlamda tüketicilerin bu mal veya hizmet için beklentilerini yönlendirmektedir. Bununla birlikte marka sahibinin kanuni çerçevede markanın kullanıldığı mal veya hizmetin kalitesini değiştirmesi mümkündür. Fakat piyasa şartları gereğince markanın kalitesinin garanti edilmesi çok gereklidir (Yılmaz, 2015: 9).

Bir teşebbüsün mal veya hizmetlerini başka bir teşebbüsün mal veya hizmetlerinden ayırt etmeye yarayan ve markanın ayırt etme, köken belirtme işlevleri günümüzde önemini yitirerek, yerini garanti işlevine bırakmıştır. Markanın tüketiciye garanti ettiği kalite sadece mal veya hizmetin objektif ve fiziksel olarak sahip olduğu niteliklerden ibaret olmayıp, markanın tüketiciler üzerindeki psikolojik etkisi de yapılan araștırmalar neticesinde ortaya çıkmıştır.

Fikri mülkiyet hukukunda markalar; ticaret markaları, hizmet markaları, ortak marka ve garanti markası olmak üzere dört grup altında incelenmiştir. Çalışma konumuzu ise garanti markalarından doğan sorumluluğun sigortalanması oluşturduğundan, diğer marka türlerine çalışmada ayrıntılı şekilde yer verilmeyecektir.

Garanti markaları, marka sahibinin kontrolü altında, bu markayı kullanmaya yetkili kılınmış birçok işletme tarafından üretilen mal ve / veya hizmetlerin ortak özelliklerini, üretim usullerini, coğrafi kaynaklarını ve kalitesini garanti etmeye yarayan işaretlerdir. Bu sebeple bir malın Türk standartlarına uygun olduğunu ve kaliteli şekilde üretilip piyasaya sunulduğunu gösteren TSE veya Uluslararası kalite normlarına uygun olduğunu gösteren ISO 9000, 9001, 9002 işaretleri de garanti markası olarak kabul edilmektedir.

Garanti markasını kullananlar ile alıcılar (tüketiciler) arasında bir sözleşme ilişkisi olması halinde, mal veya hizmetin belirtilen standartlara uygun olmaması nedeniyle zarar gören alıcı, TBK m. 219' da düzenlenen ayıba karşı tekeffül veya TBK m. $475^{\prime}$ te düzenlenen iş sözleşmesi hükümleri çerçevesinde uğranılan zararı garanti markasını kullananlardan talep edebileceği gibi; aralarında böyle bir sözleşme iliş̧isi bulunmaması halinde 6502 sayılı Tüketicinin Korunması Hakkında Kanun (TKHK) kapsamında zararının giderilmesini isteyebilecektir. Garanti markası sahibi, işaretin kullanılmasıyla kendi belirlediği standartlarda herhangi bir eksiklik olmadığını ve herhangi bir zararın doğmayacağını temin etmektedir. Alıcı bu garanti işaretlerine güvenerek sözleşme kurmaktadır. Bu sebeple garanti markası işaretini sigortalayarak sağlayıcılar(üreticiler) üzerindeki sorumluluğu bir nev'i arttırması mümkündür.

Alıcıların garanti markası sahiplerinden uğramış oldukları zararın tazminini talep etmesi mümkünken garanti markasının güvenceden doğan sorumluluğu sigortalaması çalışma konumuzun esasını oluşturmaktadır. Her ne kadar garanti markası sahibi ile alıcılar arasında bir sözleşme ilişkisi bulunmasa da sözleşme görüşmeleri esnasında üçüncü kişi konumundaki garanti markası sahibinin vermiş olduğu güvene dayanarak sözleşme yapmaya karar veren ve bu sözleşmeyle malın belirtilen özelliklere sahip olmaması nedeniyle zarar gören alıcının, bu zararlarını garanti markası sahibinden talep edebilmesi gerekir. Garanti markasına yöneltilen bu talebin garanti markasının sigortalanması marifetiyle çözüme kavuşturulması gerekmektedir(Caner-Şahin, 2013: 357).

Garanti markaları başlı başına değerlendirilmesi gereken sorunları içinde bulundurmaktadır. Bazı işaretlerin garanti markası işlevinin olup olmadığı doktrinde tartışmalıdır. Garanti markalarından doğan sorumluluğun sigortalanması hususuna ise daha önce değinilmemiştir. Çalışmamızın konusunu oluşturan "Garanti Markasından Doğan Sorumluluğun Sigortalanması" birçok açıdan ele alınmıştır. Öncelikle, markanın ne olduğundan, garanti markasının 6769 sayılı Kanun'daki 
yerinden bahsedilmiştir. Ardından garanti markası nedeniyle oluşan sorumluluktan ve doktrinde sorumluluğun kaynağının neler olabileceğine ilişkin tartışmalara yer verilmiștir. Son olarak garanti markalarından doğan sorumluluğun sigortalanması hususunda değerlendirilmelerde bulunulmuştur.

\section{GARANTI MARKALARI NEDENIYLE SORUMLULUK}

\subsection{Genel Olarak Marka}

Bir teşebbüsün mal veya hizmetlerini başka bir teşebbüsün mal veya hizmetlerinden ayırt etmek amacıyla kullanılan marka; kişi adları dâhil, sözcükler, şekiller, harfler, sayılar, malların biçimi veya ambalajları gibi çizimle görüntülenebilen veya benzer biçimde ifade edilebilen, baskı yoluyla yayınlanabilen ve çoğaltılabilen her türlü işaretleri ifade etmektedir (Marka kavramına ilişkin ayrıntılı bilgi için bknz. Arkan, 1997, 35 vd.; Yosmaoğlu, 1978: 109, 110; Dönmez, 1992: 1-2; Poroy/ Yasaman, 2018,: 413 vd.; Aslan ve Șenyüz ve Ergün, 2002: 281,282; Camcl, 1999: 6 vd.; Şanal, 2006: 10 vd.; Dirikkan, 2003,: 5 vd.).

Ticari marka, belirli bir ürün veya hizmetin kaynağını tanımlamak için kullanılan bir kelime, isim, sembol veya bașka bir cihazdır. Ticari markaların çoğu, ya düz metin biçiminde (en geniș kapsama biçimi) ya da stilize bir görünüme sahip (Örneğin, Coca Cola ve IBM gibi markaların olușturulduğu yeni yazı tipleri), logolar, tasarımlar şeklinde ifade edilen kelimeler ve renkler, șekiller, kokular ve seslerden oluşmaktadır(Contreras, 2018: 2). Bir ticari marka olmak için, marka olarak kullanılmak istenen işaret ticarette kullanılmalı, ayırt edici olmalı ve zaten kullanımda olan bir işaret ile kafa karıștırıcı șekilde benzememelidir. Kiși, ticari markaları yalnızca, benzer bir işareti kafa karıștırıcı benzer bir şekilde kullanabilecek herhangi birinden önce, kaynak göstergesi olarak mal veya hizmetlerle bağlantılı ayırt edici biçimde kullanmalıdır. Bir ticari markanın sergilediği ayırt edilebilirliğin derecesi, marka olarak kullanılabilme kabiliyetini, tescil için uygunluğunu ve uygulanabilirliğini etkilemektedir.

Günümüzde markanın ayırt etme ve köken belirtme işlevleri her geçen gün önemini yitirmekte; tüketiciler markayı bu markanın konulduğu malların aynı olduğunu belirten, bunu garanti eden bir işaret olarak kabul etmektedirler. Malın kalitesinin ve niteliklerinin markanın önceki malları ile aynı olması ve tüketicilerde oluşturduğu güven duygusunun zedelenmemesi markanın yegane işlevidir. Bu bakımdan markanın tüketiciye tercih ettiği malda belli bir standardı sağlama işlevinin bulunduğunu söylemek yerinde olacaktır(Dirikkan, 2003: 14).

Marka aynı zamanda tüketiciye, o malın bozuk olması ihtimalinde malın iade alınacağı ve yenisiyle değiştirileceğini de garanti eder; çünkü markalı ürün tüketiciye o malın nerede, ne şekilde ve hangi standartlarda üretildiğinin de garantisini vermektedir. Marka sahibi açısından asıl önemli olan husus, müşteri memnuniyetini sağlamak olduğundan; müşterilerine sağladığı güveni korumak isteyen marka sahibi de tüketiciye aynı malı aynı kalitede sunmak durumundadır. Bunun dıșında markasız ürünlerde tüketici menfaatlerinin gözetilmediğini ve bunların kısa vadeli yatırımları hedeflediğini bilen tüketiciler, bu ürünlere şüpheli yaklaşmaktadırlar(Sert, 2007: 3738).

Markanın tüketiciye garanti ettiği kalite yalnız malların objektif ve fiziksel olarak sahip olduğu niteliklerden ibaret değildir. Bunun dışında yapılan testler sonucunda birçok tanınmış markaya ait malların, daha az bilinen markaların kullanıldığı ile aynı hatta daha düşük kalitede olduğu ortaya çıkmıştır. Bu nedenle marka yalnız objektif kalite özelliklerini değil; bunun dışında tüketicinin psikolojik olarak inandığı başka özellikleri de temsil etmektedir(Dirikkan, 2003: 15). Garanti işlevi yalnız malın kalitesi açısından önem taşımaz. Bunun dışında pahalı ve lüks mallara oranla, birçok üretim malının satışa konu malın miktarı ve ebadının da aynı kalması tüketiciler açısından önem arz etmektedir. Bu nedenle üreticinin uzun bir süre markanın muhataplarına sunduğu kalite ve buna paralel olarak imajını da muhafaza etmesi ve belirli bir pazar olgunluğunun yakalanması suretiyle marka, tüketici açısından üretici ve mal yönünden bir güven oluşmasını sağlamaktadır(Dirikkan, 2003: 15). 
Emekten ve masraftan tasarruf tüketici için önem arz etmektedir. Marka emek ve masraftan tasarruf edilmesinin aracıdır. Tüketici markalı malın kalitesinin aynı kaldığını düşündüğü için alışveriș esnasında bu malın kalitesi konusunda bilgi alma zorunluluğu hissetmemektedir. Ayrıca, markanın garanti fonksiyonu sayesinde malların üretimi, pazar şeffaflığı ve edim rekabeti de teşvik edilerek toplum menfaatleri de korunmaya çalıșılmaktadır(Dirikkan, 2003: 16).

Bir teșebbüsün mal veya hizmetlerini başka bir teşebbüsün mal veya hizmetlerinden ayırt etmeye yarayan markanın, çeşitli türleri bulunmaktadır. Fikri mülkiyette markalar klasik olarak ticaret markası (trademark for good) , hizmet markası (service markası), ortak marka (collective mark) ve garanti markası (certification mark) olmak üzere dört grup altında incelenebilir. Ticaret markası bir işletmenin imalatını, ticaretini yaptığı malları başka işletmelerin mallarından ayırmaya yarayan işaret șeklinde tarif edilmiștir. Hizmet markası, bir işletmenin hizmetlerini diğer işletmelerin hizmetlerinden ayırt etmeye yarayan işaretlerdir. Ortak marka, bir grup tarafından kullanılan ve grubun ürettiği mal veya hizmetin diğer işletmelerin mal veya hizmetlerinden ayırt edilmesini sağlayan işaretlerdir (SMK m.31/3). Garanti markası ise, marka sahibinin kontrolü altında birçok işletme tarafından o işletmelerin ortak özelliklerini, üretim usullerini, coğrafi menșelerini ve kalitesini garanti etmeye yarayan işaretlerdir (SMK m.31/1). Çalıșmamızın esasını oluşturan garanti markaları bir sonraki bölümde ayrıntılı șekilde incelenecektir.

\subsection{Garanti Markaları}

\subsubsection{Genel Olarak Garanti Markaları}

6769 sayılı Sınai Mülkiyet Kanunu m. 31'de garanti markaları marka sahibinin kontrolü altında birçok işletme tarafından o işletmelerin ortak özelliklerini, üretim usullerini, coğrafi menşelerini ve kalitesini garanti etmeye yarayan işaret olduğu düzenlenmiştir. Ancak bu tanım yanıltıcıdır. Zira garanti markasında markanın garanti etme niteliği bu markayı kullanan işletmelere yönelik değil, işletmenin ürettiği mal ve hizmete yöneliktir. Bu nedenle garanti markası, marka sahibinin izni ve kontrolü altında farklı işletmeler tarafından kullanılan, söz konusu işletmelerin ürettikleri mal veya sundukları hizmetlerin ortak özelliklerini, üretim usullerini, coğrafi kaynaklarını ve kalitesini garanti etmeye yarayan işaret olarak tanımlanabilir(Suluk ve Karasu ve Nal, 2017: 172).

Garanti markasına ilișkin yapılan bu tariflerden de anlaşlacağı üzere, bu markaların değişik işletmeler tarafından üretilen mal veya hizmetlerin ayırt edilmesi işlevleri bulunmamaktadır. Ancak bu markalar işletmelerin ortak özelliklerini, mal veya hizmetin üretim usullerini, coğrafi menşelerini ve kalitelerini garanti altına alırlar. Bu nedenle bir malın Türk standartlarına uygun olduğunu ve kaliteli şekilde üretilip piyasaya sürüldüğünü gösteren TSE veya Uluslararası Kalite normlarına uygun üretildiğini gösteren ISO 9000, ISO 9001 ve ISO 9002 işaretleri klasik anlamda marka olmamakla birlikte, 6769 sayılı Kanun ile garanti markası olarak nitelendirilmiş ve klasik markaların tabi olduğu hükümlere tabi kılınmıştır. Örneğin; Uluslararası Yün Birliği' ne ait "Woolmark" markası, şartlarını birliğin koyduğu yünden mal üretenler tarafından birlikten izin alınmak suretiyle kullanılır. Bir yün kumaş üzerinde "Woolmark" markasını gören kişi, bu kumaşın kalitesinin nasıl olduğunu ve bunun Birlik tarafından garanti edildiğini bilmektedir. Bunun gibi, Sri Lanka Cumhuriyeti Çay Heyeti tarafından (Tea Board) kullanma hakkı verilen, Srilanka Devleti Bayrağında yer alan "aslan amblem ve logosu" da bir tür garanti markası niteliğinde olduğundan, bu logo ancak kuruluştan izin alınarak Seylan çay ambalajlarında kullanılabilecektir. Ayrıca Zürich Üniversitesi Dişçilik Enstitüsü'nün sahibi olduğu ve diş çürümelerine neden olmayan sakızlarda kullanılan (diş üzerinde şemsiyeden oluşan resimli) işaret de başka bir garanti markası olduğu gibi Avrupa Birliği' ne ihraç edilecek bazı mallar için kullanılması zorunlu olan " $C E$ ” işareti de garanti markalarındandır(Caner-Şahin, 2013: 362).

Garanti markasını diğer markalardan ayıran hususlardan biri bu markanın sahibi veya ona iktisaden bağlı olan işletmenin mal veya hizmetlerinde kullanılmayacak olmasıdır(SMK m.31/2). Sağlayıcıların hem üretimi sağlayıp hem de standartların belirlenmesinde kontrolü elinde bulundurmaları birtakım zorluklara neden olacağı göz önünde bulundurularak böyle bir 
düzenlemeye gidilmiştir. Hükümde garanti markasının marka sahibine iktisaden bağlı bir işletmenin mal veya hizmetlerinde kullanılması da yasaklanmıștır. Bu ifade ile yalnız marka sahibinin yönettiği şirketler değil, ondan tarafsız bir denetim beklenemeyecek olan diğer şirketler anlaşılmalıdır. Nitekim bu şirketlerin de garanti markasını kullanmaları mümkün değildir. Garanti markası sahibi markayı bizzat kullanmamasına rağmen markanın, marka sahibinin belirlediği ve teknik yönetmelikteki nitelikleri taşıyıp taşımadığı marka sahibi tarafından denetlenir ve devamlı surette kontrol edilir(Meran, 2004: 32).

\subsubsection{Güven Duyulan Marka}

Garanti markasına benzer bir kavram olarak son yıllarda "güven duyulan marka" kavramı ortaya çıkmıştır. Güven duyulan marka 90'lı yılların sonundan itibaren e-ticarette kullanılmaya başlanmış; bu yıllarda çok sayıda güven duyulan marka kurulmuş ve güven duyulan markalar işletmelerin web sayfalarında daha fazla görülmeye başlanmıştır.

Marka güveninin birçok çalıșmada(Doney ve Cannon, 1997: 35-51; Moorman ve Zaltman ve Deshpande, 1992: 314-328) merkezi olduğu düşünülmektedir. Firma başarısında dikkate değer bir faktör olarak kavramsallaștırılmıştır(Morgan ve Hunt, 1994: 31). Chaudhuri ve Holbrook (2001) marka güvenini "ortalama bir tüketicinin markanın belirtilen ișlevini yerine getirme yeteneğine güvenme isteği" olarak tanımlamaktadır. Marka güveni, tüketicilerin şirketlerin tekliflerini değerlendirmesinden sonra ortaya çıkar. Şirketler tüketicileri için markaları hakkında güvenlik, dürüstlük ve güvenilirlik inancı sağlarsa marka güveni oluşacaktır. Marka güveninin, tüketicilerin markalar aracılığıyla doğrudan deneyimleriyle yaratıldığı ve geliștirildiği yorumlanabilir (Kabaydayı ve Koçak-Alan, 2012: 81).

Marka güveni ve marka etkisi arasındaki temel fark; marka güveni, mağaza hakkında tüketici deneyimlerinin dikkate alınmasıyla oluşabilecek uzun bir süreç olarak görülürken, marka etkisi kendiliğinden oluşabilecek dürtüsel duygulardan oluşmaktadır. Bu nedenle marka güveni, duygusal tepkiye, yani marka etkisine neden olabilecek bir bileșen olarak düşünülebilmektedir(Chaudhuri ve Holbrook, 2001: 89).

E-ticarette tüketici güveninin sağlanması yollarından biri de güven duyulan markalardır. Yapılan bir tarife göre güven duyulan marka, devlet, endüstri ve tüketici grupları tarafından birlikte meydana getirilen bağımsız bir inisiyatiftir. Güven duyulan markadan e-alışveriş yapan bireyler için artırılmış bir tüketici koruma seviyesi sağlamak üzere tasarlanmıştır. Bu anlamda güven duyulan marka bireylerin e-alışverişlerinde gördüklerinde güvenebilecekleri bir logo ile temsil edilmekte, bu logoyu taşıyan tacirlere ise tüketiciler "yüzde yüz" güvenmektedirler.

Güven duyulan marka, tüketicilere güvenli olduğu onaylanan mağazalardan alışveriş̧ yaptıklarında, bu mağazaların öngörülen kurallara uygun hareket ettiklerini bilmelerini sağlayarak tüketicilerde güven hissi uyandırmaktadır. Güven duyulan markanın aynı zamanda müşteriyi kendi ülkesinde uygulanan kuralların başka bir AB ülkesinden alışveriş yaptığı zaman o ülkede de uygulandığı konusunda bilgi verme işlevi vardır.

Güven duyulan markaların çoğu, genellikle e-ticarette tüketici güvenliğini artırmayı amaçlamaktadır. Bu amaçlarla oluşturulan güven duyulan markaların çoğu son birkaç yıl içerisinde oluşturulmuş ve bazen yalnız özel sektör veya kamu sektörüne ait işbirlikleri şeklinde ortaya çlkarlarken bazen de tüketiciler ve işletme organizasyonları arasındaki işbirlikleri olarak ortaya çıkmaktadırlar.

Klasik ticari hayatta ise güven duyulan marka işlevini gören birtakım araçlar bulunmaktadır. $\mathrm{Bu}$ anlamda SMK m. 31'de düzenlenen garanti markaları da bu araçlardandır.

\section{GARANTI MARKALARI NEDENIYLE SORUMLULUK}

Garanti markaları nedeniyle, alıcının zarar görmesi halinde bu zarardan kim veya kimlerin hangi nedenlerle sorumlu tutulması gerektiği üzerinde önemle durulması gereken konulardan birini oluşturmaktadır. Alınan mal veya hizmetin garanti markası ile kefil olunan özelliklere sahip 
olmaması ihtimalinde garanti markasını kullanan satıcı veya üretici TBK m.219'da hükme bağlanan ayıba karşı tekeffül hükümleri çerçevesinde sorumlu olacaktır. Ayrıca TBK m.475 hükmü gereğince, iş sahibi kullanamayacağı veya insaf ölçülerine göre kabule zorlanamayacağı derecede kusurlu bir şeyi kabul etmeme hakkına sahip olduğu gibi; zarar ve ziyanın karşılanmasını dahi isteyebilecektir. Garanti markasını kullanan kişi ile alıcılar arasında bir sözleşme ilişkisinin olmaması halinde ise alıcılar ayıplı maldan ve bu malın neden olduğu zararlardan satıcı ile üreticiyi müştereken ve müteselsilen sorumlu tutan TKHK hükümleri çerçevesinde markayı kullanan kişiden talepte bulunabileceklerdir(Caner-Şahin, 2013: 364)..

Bir garanti işareti, genellikle, bir ticari marka türüdür. Bununla birlikte, tüketiciye belirli bir ürünün veya hizmetin kaynağını göstermesi amaçlanan ticari markaların aksine, garanti işaretlerinin, bir ürünün belirli özelliklerini, ürünün incelemesinden kolayca ayırt edilememesi durumunda tüketicilere tanımlaması amaçlanmıştır. Bir ürünün güvenlik, güvenilirlik veya üretim süreci ile ilgili belirli gereklilikleri karşıladığını belirtmek için garanti markası kullanılır. Örneğin Amerika'da en iyi bilinen sertifika işareti, dünya Underwriters Laboratories'in " $U L$ " sertifikasıdır. Underwriters Laboratories, markasının mutfak aletlerinden yangın söndürücülere ve endüstriyel halıya kadar yılda 22 milyar üründe göründügünü iddia edilmektedir. UL, ürünleri kendi standartlarına uygunluk ve geliştirilen standartlar için test eder ve onaylar(UL sertifikası almak, ABD'deki birçok ürün kategorisi için ticari bir gereklilik olarak görülmektedir.). Türkiye'de bu durum "Türk Standartları Enstitüsü" tarafından kontrol edilmektedir.

Garanti markasını kullananların TBK ve TKHK hükümlerine göre sorumlu tutulmaları gerektiğini tespit ettikten sonra, garanti markası sahibinin sorumluluğu ve bu sorumluluğun sigortalanabilmesi üzerinde de durulması gerekir. Bu hususta doktrinde Arkan tarafından ileri sürülen bir fikre göre, garanti markası sahibi, alıcılar arasında bir sözleşme ilişkisinin bulunmaması ve sınırlı bir denetim imkânına sahip olunması nedeniyle alıcıya karşı sorumlu tutulmamalıdır. Kural bu olmakla birlikte, marka sahibinin gerekli denetimden kaçınması ve markanın yetkisiz kişiler tarafından kullanılması karşısında sessiz kalması ihtimalinde aykırı kullanım kabul edilerek markanın hükümsüzlüğü yoluna gidilebilir.

Doktrinde Poroy/ Yasaman ise garanti markasında belirlenen niteliklere uyulmaması halinde, garanti markasını kullanan ve garanti markasının sahibinin sorumlu olduklarını belirtmekle birlikte, bu sorumluğun hukuki niteliğine ilişkin herhangi bir açıklamada bulunmamışlardır. Kanaatimizce, garanti markası sahiplerini alıcılar ile aralarında bir sözleşme ilişkisinin bulunmaması ve sınırlı bir denetim imkânına sahip olmaları nedeniyle alıcılara karşı sorumlu tutmamak mümkün değildir. Nitekim günümüzde sözleşme tarafi olmamakla birlikte, sözleşmenin karşı tarafın da haklı güven oluşturan ve bu güven neticesinde karşı tarafı sözleşme yapmaya sevk eden kişilerin de TMK m. 2' de kanuni dayanağını bulan güven esasına göre sorumlu olacağı hakim doktrin tarafından kabul edilmektedir. Bu nedenle sözleşme görüşmeleri aşamasında mal veya hizmet alıcılarına ürünlerde belli özelliklerin bulunduğuna ilişkin sorumluluğu üzerine alan garanti markası sahipleri de, alıcı ile doğrudan temas halinde bulunmasalar dahi güven esası uyarınca sorumlu olmalıdırlar.

\section{GARANTI MARKASINDAN DOĞAN SORUMLULUĞUN SİGORTALANMASI}

WIPO (Dünya Fikri Mülkiyet Teşkilatı) tarafından tanımlanan fikri mülkiyet, "zihnin yarattıkları: icadı ve sanatsal eserler, semboller, isimler, görüntüler ve ticarette kullanılan tasarımlar" anlamına gelir. İki kategoriye ayrılmıştır: Buluşları (patentleri), ticari markaları, endüstriyel tasarımları ve kaynağın coğrafi göstergelerini içeren sınai mülkiyet; ve çizimler, resimler, fotoğraflar, heykeller ve mimari tasarımlar gibi edebi ve sanatsal eserleri içeren telif hakkı. Telif hakları ile ilgili haklar, performanslarında sanatçıların performanslarını, kayıtlarında fonogram üreticilerini ve radyo ve televizyon programlarında yayıncıların haklarını içermektedir.

Sınai mülkiyet haklarının korunması, mahkeme ve adli korumaya bağlı olduğu için hem marka sahibine hem de karşı tarafa birtakım ek masraflar yüklemektedir. Bu koşullarda, fikri mülkiyet sigortasının kullanılması fikri mülkiyet haklarının korunmasıyla ilgili kayıpların telafi edilmesine 
izin vermektedir. Bu nedenle, fikri mülkiyet haklarının özellikleri ve fikri mülkiyet haklarının ihlali oranının artmasıyla bağlantılı ek risklerle ilgili fikri mülkiyet alanının güvence altına alınması gerekmektedir. Bu bağlamda, fikri mülkiyet haklarının satın alınması, elden çıkarılması ve ekonomik olarak devrilmesi ile ilgili işlemler her zaman ilgili sigorta hizmetlerinin uygulanması ile birleştirilmelidir(Smit, 2018: 423).

Fikri mülkiyet sigortasının amacı, işletmelerin entelektüel güvenliğinin seviyesini artıran entelektüel faaliyet sonuçlarının atanması ve ticarileştirilmesine ilişkin ekonomik ilişkilerin katılımcılarının değerli çıkarlarının korunmasıdır.

Fikri mülkiyet haklarının korunması, dünyadaki her gelişmiş ülkenin gümrük politikasının bir bileşenidir. Bu sebeple, fikri mülkiyet haklarının ihlaliyle üretilen veya dağıtılan mallar, ilgili ülkenin topraklarına ithal edilemez. Bu nedenle, günümüzde küresel pazarlardaki rekabetçi faaliyetlerin ana yöntemlerinden biri, șirketler fikri mülkiyet haklarını ihlal eden ekonomik aktörler üzerinde baskı olușturmak için aktif olarak yasal iddialar kullanarak güvenlik politikaları geliștirmektedir. Bazı șirketler bu tür rakiplerin malları için bazı ulusal pazarları kapatmaktadırlar. Örneğin, Apple ve Samsung arasındaki uzun patent savaşı.(2011 yılında Samsung'un Galaxy Tab serisinin iPad'in patent haklarını ihlal ettiği ve sonrasında Samsung tarafından Apple'a açılan Apple'ın, kendisine ait 10 patenti ihlal ettiğinin öne sürülmesinden oluşmaktadır.)

Bu gibi durumlarda, sorumluluk sigortası, fikri mülkiyet konularının üçüncü taraflarca saldırgan rekabet politikasının uygulama risklerini azaltmalarına ve fikri mülkiyet haklarının hukuken korunmasına ilişkin harcamaları telafi etmeyi mümkün kılmaktadır.

Güvenlik markasının sahibi, işaretinin kullanımını da kontrol etmekle yükümlüdür. Aksi halde kontrol eksikliği, garanti markasının tescilinin iptali ile sonuçlanabilmektedir(Mccarthy, 2016: 92). Marka sahibinin sunduğu garantinin kullanımını standartlara uygun kontrol etmemesi bu sorunu oluşturmaktadır. Spesifik olarak, bir marka sahibi, ürün veya hizmetlerin garanti markasını kullanma izni vermeden önce TSE standartlarına uygun olduğunu doğrulamazsa, marka sahibinin kontrol eksikliği olduğu tespit edilebilmektedir. Örneğin; Midwest Plastic Fabricators, Inc. v. Underwriters Laboratories Inc.(Case 90-1043), kontrolü, tüketicilerin markayı taşıyan malların belirli niteliklerini gösteren bir garanti markası işaretiyle yanlış yönlendirilme riskinin artması nedeniyle önem arz etmektedir. Tam kontrol gerekli değildir; marka sahibi sadece "markalarının kullanımını kontrol etmede dikkate değer bir özen" göstermelidir. Garanti markası sahibi, ürün ve hizmetleri kişisel olarak "işareti taşıyan ürünlerin standartlara uyduğunu halka açıklamak ilan etmek" zorunda değildir(Smit, 2018: 420). Burada ilgili soru, kontrolün gerçekten sürdürüldüğü bir noktada üçüncü kişilerin zarar görmesi ve bu zararın garanti markası sahibi tarafından karşılanmasıdır. Bu noktada oluşan sorumluluk Türk hukukundaki "ürün sorumluluğu sigortası"na benzetilebilmektedir. 6098 sayılı Borçlar Kanunu'nun haksız fiil ve kusursuz sorumluluğa ilişkin hükümleri, özel olarak da 6502 sayılı Tüketicinin Korunması Hakkında Kanun ile düzenlenmiş bulunmaktadır. 6502 sayılı Kanun m.4'te "Ayıplı Mal ve Hizmetler" başlığı altında, "Ayıplı maldan ve/veya ayıplı malın neden olduğu her türlü zararlardan dolayı tüketiciye karşı garanti markası sahibi sorumlu olacaktır." șeklinde düzenlenmiştir. Garanti işaretine güven duyularak alınan malın ayıplı olduğunun bilinmemesi bu sorumluluğu ortadan kaldırmamaktadır.

"Mal" ve "ayıplı mal" kavramı 13 Haziran 2003 tarihli Resmi Gazete'de (25137 sayılı Resmi Gazete) yayınlanarak yürürlüğe girmiş olan "Ayıplı Malın Neden Olduğu Zararlardan Sorumluluk Hakkında Yönetmeliğin" 4. maddesinin c fikrasında "mal" kavramı alışverişe konu olan taşınır eşyayı, konut ve tatil amaçlı taşınmaz malları ve elektronik ortamda kullanılmak üzere hazırlanan yazılım, ses, görüntü ve benzeri gayri maddi malları ifade ettiği; "ayıp" kavramı ile ilgili olarak "Malın piyasaya sunum tarzı, makul kullanım șekli ve piyasaya sürüldüğü an ve benzeri diğer hususlar göz önüne alınarak, bir kimsenin o maldan haklı olarak bekleyebileceği güvenliği sağlamayan mal ayıplı sayılır." şeklinde düzenlenmiştir. 
Yönetmeliğin 6. maddesinde "Ayıplı bir malın, bir kişinin ölümüne veya yaralanmasına veya bir malın zarar görmesine sebep olması halinde imalatçı/üretici doğan zararı, kusuru aranmaksızın tazmin etmekle yükümlüdür." denilmekle, asıl üreticinin sorumluluğu saklı kalmak kaydıyla, ișinin seyri içinde satış, herhangi bir dağıtımını yapma amacıyla bir ürün imal eden kişi, Yönetmelikte üretici olarak kabul edilmektedir. Türk hukukunda da Avrupa ve diğer gelişmiş ülkelere paralel olarak "ürün sorumluluğu" kusursuz sorumluluk hali olarak belirlenmiştir(Ünal, 2015:9) Garanti markası sahibi temin ettiği markanın/ürünün verebileceği zararlardan kusursuz olarak sorumlu tutmak yerinde olacaktır. Genel hüküm olan kusur sorumluluğundan daha ağır tutulan kusursuz sorumluluk hükümlerine tabi olması garanti markası sahibinin marka işaretlerini daha dikkatli ve sonuçlarını hesaplayarak ürününe koymasını sağlayacaktır.

Kusursuz ürün sorumluluğu uygulanırken, üründeki güvenlik eksikliğinin tespiti, sorumluluğun kuruluşu açısından önem arz etmektedir. Bir ürünün güvenli olup olmadığını belirlemedeki temel ölçüt, toplumun üründen beklediği objektif güveni sağlayıp sağlamadığıdır. Buradaki objektif güven, ürünün insanların can ve mallarını azami ölçüde koruyacak şekilde üretildiği varsayımıdır. Piyasaya tedavül edilen bir ürün kișilerin can ve mallarını beklenen azami ölçüde koruması gerekmektedir.(Dinç, 2017: 110,111) Ürünün kendisinden beklenen objektif güveni sağlayıp sağlamadığı tüm koşulların dikkate alınması ve her somut olaya göre değerlendirme yapılması ile mümkündür(Duffy, 2015: 154). Güvenli olduğu garanti markaları tarafından onaylanmış ürünler de zarara sebep olabilir. Bu durumda, ürünün niteliği gereği kişilerin vücut bütünlügüne veya diğer mallarına zarar verebiliyorsa, bu zararla ürün sorumluluğu kapsamında tazmini gerekmez(Aslan, 2010: 214). Bir başka değişle, bir ürünün niteliği gereği normal kullanımından doğan zararlar ürün mali sorumluluk sigortası kapsamında değildir.

TKHK m.10/3. fikrasında "Teknik düzenlemesine uygun olmayan ürünler ise hiçbir şekilde piyasaya arz edilemez." hükmü ile garanti markalarının hazırladığı standartlara uymayan ürünlerin piyasaya sunulmayacağı düzenlenmiştir. Teknik düzenleme, TKHK'nun üçüncü maddesinin birinci fikrasının j bendindeki düzenlemeyle 29/6/2001 tarihli ve 4703 sayılı "Ürünlere İlişkin Teknik Mevzuatın Hazırlanması ve Uygulanmasına Dair Kanun"da "Bir ürünün, ilgili idarî hükümler de dahil olmak üzere, özellikleri, işleme ve üretim yöntemleri, bunlarla ilgili terminoloji, sembol, ambalajlama, işaretleme, etiketleme ve uygunluk değerlendirmesi işlemleri hususlarından biri veya birkaçını belirten ve uyulması zorunlu olan her türlü düzenlemeyi," şeklinde hükmedilmiștir. Ürün güvenliği Kanunu teknik düzenlemeler bakımından, her sektöre ilişkin ayrı kriterler belirlememiş, güvenli ürün için gerekli standartları genel hatlarıyla belirtmiştir. Her ürünün güvenlik standartları, ürüne ilişkin sektörün kendi teknik ve idari düzenlemelerinde belirlenmektedir. Örneğin, Türk Standartları Enstitüsü kendi belirlediği teknik ölçütlere uyulmasını zorunlu kılmış ve garanti işaretinin kullanımına bu ölçüde izin vermektedir.

Üreticinin standartlara uygun davranmasına rağmen, standartların hatalı olduğunun sonradan anlaşılması halinde, üreticinin davranışı hukuka aykırılık teşkil etmemektedir. Bu durumda standartları belirleyen garanti markalarına sorumluluğun yükletilmesi hususu gündeme gelecektir. Bazı yazarlar(Aslan, 2015: 132, Hanımeli, 1999: 27) oluşacak zararların Güvence Hesabı benzeri bir fondan karşılanmasının hakkaniyete uygun olacağını belirtmişlerdir. Ayıplı Malın Neden Olduğu Zararlardan Sorumluluk Hakkında Yönetmelik m.7/1'inci maddesinin d fıkrasında, ürüne ilişkin standartları belirleyen emredici hükümlere uygun davranılmış olunması bir zarara sebebiyet verirse, bu durum üretici için sorumluluktan kurtuluş nedeni olduğu düzenlenmiştir. $\mathrm{Bu}$ durumda, sorumluluğun garanti markası sahibine karşı yöneltilmesi gerekmektedir. Ürün sorumluluğu sigortasının kapsamının, rizikonun sınırlarının ürünün niteliğine göre belirlenmesi ve sorumluluğun genişletilmesi gerektiği kanaatindeyiz.

Ürün sorumluluk sigortası sorumluluk risklerinin sigortacılar tarafından kontrollü bir șekilde üreticilerden devralınarak üretici firmaların varlığını tespit edebilecek tazminat taleplerine karşı koruma sağlanmasının yanında itibarlarının korunması ve haksız taleplerine karşı savunma sağlanmayı amaçlamaktadır. Ürün sorumluluğu sigortası ile üretici gelecekte maruz kalabileceği sorumluluklardan kaynaklanabilecek ve miktarı o an için belirsiz olan tazminat talepleri yerine,

\section{$\mathbf{R} \& S$}

Research Studies Anatolia Journal

Volume:3, Issue: 1, January 2020 
miktarı belirli olan sigorta primini ödeyerek, sigorta poliçesi süresince karşılaşabileceği tüm sorumluluk giderlerini amorti etmektir(Milli Eğitim Bakanlığı, 2011: 9).

Sorumluluk sigortalarında rizikodan bahsedebilmek için her şeyden önce sigorta ettirenin malvarlığında bir kötüleşmenin meydana gelmesi veya en azından böyle bir kötüleşme olasılı̆̆ının ortaya çıkmış bulunması zorunludur. Ürün sorumluluğu sigortası zarar sigortası niteliğinde oldukları için sorumluluk sigortalarında da sigortacı ancak sigorta ettirenin malvarlığı bir kötüleşmeye (veya kötüleşme tehdidine) maruz kaldığı takdirde koruma edimini (dinamik olarak) yerine getirecektir.

$\mathrm{Bu}$ sigortalarda rizikoyu özelleştiren husus sigorta ettirenin sorumluluğudur. Bu bakımdan, sigorta ettirenin malvarlığında sigorta ettirenin sorumluluğu dışındaki bir sebeple meydana gelen kötüleşmeler (örneğin, sigorta ettirene ait bir eşyanın çalınması, doğal afet yüzünden yok olması vb.) sorumluluk sigortalarının kapsamına dahil değildir. Buna göre, sorumluluk sigortasında sigorta edilen risk, bir kișinin sorumlu olması, yani üçüncü kişilere karşı tazminat ödemek zorunda kalması tehlikesidir. Öte yandan bir sorumluluk sigortasının her türlü sorumluluğu kapsaması da teknik sebeplerle mümkün olamamaktadır. Bu yüzden, her sorumluluk sigortası belirli bir (veya bir kaç) temel sorumluluk sebebi ile sınırlı olarak koruma sağlar. Bundan başka, bir sorumluluk sigortasının kapsamakta olduğu sorumluluk zaman, yer ve miktar bakımından da sınırlanabilir. Sigortacının dinamik koruma borcu, ancak sözleşmede öngörülen zaman dilimi içinde, sözleşmede öngörülen yerlerde ortaya çıkan sorumluluklar için ve yine sözleşmede öngörülen teminat limitleri dahilinde gerçekleşir(Milli Eğitim Bakanlığı, 2011: 22).

Tüketici güveni, garanti markalarının kontrolünün arkasındaki itici faktörlerden biri olmasına rağmen, garanti markasının güvenilirliği büyük ölçüde marka sahibine bırakılmıștır. Marka sahibi standartları oluşturmakta, hangi ürünlerin markayı taşıyacağına karar vermekte ve tüketicileri garanti markasının temsil ettiği kalite standartlarını güvenilir bir şekilde sağladığına ikna etmektedir. Marka sahibinin bağımsız olarak, garanti işaretinin yetkisiz kullanımını engellemek isteyen tüketici, belirli bir markanın güvenilirliğini belirlemek için muhtemelen bu bilgilere ulaşamayacaktır. Marka sahibinin TSE standartları hakkında bilgi yayınlamaması durumunda, tek kontrol garanti işaretinde pazarın kendisi olacaktır(Smit, 2018: 424).

\section{SONUÇ}

Garanti markaları, marka sahibinin kontrolü altında bu markayı kullanmaya yetkili kılınmış birçok işletme tarafından üretilen mal ve/veya hizmetlerin ortak özelliklerini, üretim usullerini, coğrafi kaynaklarını ve kalitesini garanti etmeye yarayan işaretlerdir. Bu nedenle bir malın Türk standartlarına uygun olduğunu ve kaliteli şekilde üretilip piyasaya sunulduğunu gösteren TSE veya uluslararası kalite normlarına uygun olduğunu gösteren ISO 9000, 9001, 9002 işaretleri de garanti markası olarak kabul edilmektedir.

Garanti markasını kullanan ile alıcılar arasında bulunan hukuki ilişki nedeniyle alıcılar TBK ve TKHK hükümleri çerçevesinde uğradıkları zararı tazminini talep edebilirler.

Alıcıya mal veya hizmetin belirli standartlarda olduğuna ilişkin bilgi veren garanti markası sahibinin sorumluluğunun hukuki dayanağı güven sorumluluğudur. Bu güven sorumluluğuna dayanarak işlem yapan alıcı oluşan güven zararlarının tazminini isteyebilmektedir. Bu noktada garanti markasının sahibinin sunduğu ürünün güvencesi ayıplı malın neden olduğu zararlardan doğan ürün sorumluluğu sigortası kapsamında rizikonun sınırlarının sigorta sözleşmesinde belirlendiği şekilde sınırlı olacağı şeklinde bir değerlendirme yapılması yerinde olacaktır.

Marka sahibi "markalarının kullanımını kontrol etmede dikkate değer bir özen" göstermelidir. Garanti markası sahibi, "işareti taşıyan ürünlerin standartlara uyduğunu halka açıklamak ilan etmek" zorunda değildir. Ancak, kontrolün gerçekten sürdürüldüğü bir noktada üçüncü kişilerin zarar görmesi durumunda meydana gelen zararın garanti markası sahibi tarafından karşılanması beklenmektedir. Bu noktada oluşan sorumluluk Türk hukukundaki "ürün sorumluluğu sigortası"na benzetilebilmektedir. Ürün sorumluluğu sigortasının kapsamının, rizikonun

\section{$\mathbf{R} \& S$}

Research Studies Anatolia Journal

Volume:3, Issue: 1, January 2020 
sınırlarının ürünün niteliğine göre belirlenmesi ve sorumluluğun bu kapsamda genişletilmesi gerektiği düşünülmektedir.

\section{KAYNAKÇA}

Arkan, S. (1997). Marka Hukuku, C. 1, Ankara.

Aslan, İ. Y. (2010). Tüketici Hukuku Dersleri, Ekin Yayınevi, Bursa.

Aslan, İ. Y. (2015). 6502 Sayılı Kanun’a Göre Tüketici Hukuku, B.5, Ekin Yayınevi, Bursa.

Aslan, İ. Y.; Şenyüz, D. \& Ergün, M. (2002). İşletme Hukuku, Bursa.

Camcı, Ö. (1999). Marka Davaları, İstanbul.

Caner Şahin, A. (2013). Garanti Markaları Nedeniyle Sorumluluk, Prof.Dr. Mustafa Dural'a Armağan, Filiz Kitabevi, İstanbul.

Chaudhuri, A. \& Holbrook, M. B. (2001). The Chain Of Effects From Brand Trust And Brand Affect To Brand Performance: The Role Of Brand Loyalty, Journal of Marketing, S. 6.

Contreras, J. L. (2018). Trademarks, Certification Marks and Technical Standards, Cambridge Handbook of Technical Standardization Law, C.2: Administrative Law, Trade, Privacy, Tort, Copyright and Trademark.

Dinç, İ. D. (2017). Ürün Sorumluluk Sigortasında Rizikonun Konusu ve Teminatın Kapsamı, On İki Levha Yayıncılık, İstanbul.

Dirikkan, H. (2003). Tanınmış Markanın Korunması, Ankara.

Doney, P. M. \& Cannon, J. P. (1997). An Examination of the Nature of Trust in Buyer-Seller Relationships. Journal of Marketing, C.61, s.35-51.

Dönmez, İ. (1992). En Son İçtihatlarla Açıklamalı Markalar ve Haksız Rekabet Davaları, İstanbul.

Duffy, P. (2015). Products Liability Insurance, Kluwer's Handbook of Insurance, CCH Editions, London.

Hanımeli, Ç. (1999). Ürün Sorumluluğu Sigortası, Yayınlanmamış Yüksek Lisans Tezi, İstanbul.

Kabaydayı, T. E. \& Koçak Alan, A. (2012). Brand Trust and Brand Affect: Therr Strategıc Importance On Brand Loyalty, Journal of Global Strategic Management, C.6, S.1.

Mccarthy, J. T. (2016). Mccarthy on Trademarks And Unfair Competition, B.4, Bölüm 19.

Meran, N. (2004). Marka Hakları ve Korunması, Ankara.

Milli Eğitim Bakanlığı, (2011). Ürün Mali Sorumluluk Sigortası, Pazarlama ve Perakende.

Moorman, C. ; Zaltman, G. \& Deshpande, R. (1992). Relationshtps Between Providers and Users of Market Research: The Dynamics of Trust Within and Between Organizations, Journal of Marketing Research, C. 29, s.314-328.

Morgan, R. M. \& Hunt, S. D. (1994). The Commitment Trust Theory Of Relationship Marketing, Journal of Marketing, C.58, S.2, s.20-38.

Poroy, R. \& Yasaman, H. (2018). Ticari İşletme Hukuku, Vedat Kitapçılık, İstanbul.

Sert, S. (2007). Markanın Kullanılması Yükümlülügü, Ankara.

Smit, M. B. (2018). (Un) Common Law Protection of Certificiton Marks, Notre Dame Law Review, C.93, S.1.

Suluk, C. ; Karasu, R. \& Nal, T. (2017). Fikri Mülkiyet Hukuku, Seçkin Yayınevi, Ankara.

Şanal, O. (2006). İçtihatlı Açıklamalı Markalarda Hükümsüzlük Davaları, Genişletilmiş ve Gözden Geçirilmiş 2. Baskl, Ankara. 
Ünal, S. (2015). Ürün Sorumluluk Sigortası Genel Şartları ile İlgili Bir Değerlendirme, Reasürör, Milli Reasürans Ticaret Anonim Şirketi.

Yılmaz, M. (2015). Garanti Markası ve Ortak Marka Kavramlarının İncelenmesi, Türkiye Düzenlemelerinin AB ve ABD Düzenlemeleriyle Karşılaştırılması, Türk Patent Enstitüsü Markalar Dairesi Başkanlığı Uzmanlık Tezi, Ankara.

Yosmaoğlu, N. (1978). Patentler, Know How'lar Markalar, Ankara. 